\title{
The Students' Perception About Multicultural Education at the Indonesian School in Singapore
}

\author{
Dadang Sundawa \\ Civic Education Department \\ School of Postgraduate \\ Indonesia University of Education \\ Bandung, Indonesia \\ d_sundawa@yahoo.com
}

\author{
Shilmy Purnama \\ Student of Civic Education Department \\ School of Postgraduate \\ Indonesia University of Education \\ Bandung, Indonesia
}

\begin{abstract}
Indonesia is one of the big countries and consists of thousand islands. These diversities make Indonesia become one of the biggest multiculturalism countries in the world. Multiculturalism is the state of society which consists of the diversity values of religion, tribes, race, ethnic, language, and social status. However, in the application, the diversity and the plurality will cause problems, among others. Therefore, it is important to make the education that gives multicultural insight to the students in families, schools, and society environment to create the characterized, civilized, and respect the multiculturalism citizens. This study discussed the students' perception about multicultural education at the Indonesian School in Singapore. The result showed that the students' perception about multicultural education has different generated categories between junior and senior high school levels. Based on the result of $T$ test conducted on multicultural education indicator, it can be seen that $t$ count $(-21.8)<t$ table $(2.00)$; hence, students of Indonesian School of Singapore have positive perception about multicultural education. Thus, multicultural education is expected to be taught to young generation to maintain harmony relationships among fellow members of the community in diversity.
\end{abstract}

Keywords - multicultural, education, Indonesian School

\section{INTRODUCTION}

Indonesia is one of the big countries and consists of thousand islands. It has about 17.500 islands from the western tip of Sabang to Merauke. Based on the Central Bureau of Statistics or Badan Pusat Statistik (BPS) in 2010, there are 1.340 tribes in Indonesia. The diversity of language is about1.211 languages with 1.158 local languages among others which provide the value of diversity to the nation of Indonesia although it has the Indonesia language as the national language. These diversities make Indonesia becomes one of the biggest multiculturalism countries in the world. Multiculturalism is the state of society which consists of the diversity values of religion, tribes, race, ethnic, language, and social status.

What is meant by multiculturalism, in this case, is different from the other terms often mentioned. It means that the multiculturalism is not only interpreted as the diversity of differentiation, but also knowing the differentiation as the important and universal shared cultural values and as the implicit confession toward the equality of the whole cultures. If it is linked to the Indonesian context, these diversities will be a positive value if we can keep and apply the responsible diversity values in order to create the unity value of Indonesia. This is in line with the ideas proposed by the founding fathers of Indonesia that the Unitary State of the Republic of Indonesia or Negara Kesatuan Republik Indonesia (NKRI) is a country which upholds the Bhinneka Tunggal Ika (different but still one) physically, psychologically, and culturally. This sense of unity, at the end, will create the national solidarity based on the core values in social life.

However, in the application, the diversity and the plurality will cause problems, among others; conflict between religions, conflict between tribes, brawl between school students and society, and many others. This is similar as stated by [1] that:

Multiculturalism is a challenge which put forward the pluralities of the values, mechanism, and social structure in the human being frame. In the pluralism awareness, the human is put forward to the process of learning which constantly rolling over his whole life towards something out of his privacy and his/her monoculture identity.

The emergence of some threats causing multiculturalism conflicts in Indonesia will cause the society life and nation far from the values of virtue as the citizens. In fact, the civic virtue is the important thing in the life of the nation and the state in a country. The values of the civic virtue of responsibility and the justice will make someone becomes a good and intelligent citizen.

According [2], if a country with multiculturalism wants to survive, it must do two things like destroying the multiculturalism dimension on the existing society; thus, it becomes one dominant culture. This extreme thing tends to the tragic and well-known genocide in the beginning of the $20^{\text {th }}$ century. This extermination act in multiculturalism country aims to create the monoculture society as in Yugoslavia and assassination in the middle Africa.

Besides fostering the mutual respect, another effort to create Indonesia which is civilized and moralized is through applying the preventive action by the educational section, either in families' environment, school environment, or in 
society environment. The preventive action can be done in educational section to cope with multiculturalism problems. The education in Indonesia must be sensitive and preventive towards the rolling of globalization especially in coping with multiculturalism phenomena.

Therefore, it is important to make the education which gives multicultural insight to the students in families, schools, and society environment to create the characterized, civilized, and respecting the multiculturalism citizens. The multicultural education appreciates the cultural diversity as the objective reality in society life, exploring the differentiations as the inevitability, and creating the tolerant and inclusive academic culture [3].

\section{LITERATURE REVIEW}

Reference [4] stated that multicultural society is "a society composed of several types of cultural communities with all the benefits, with slight differences in world conceptions, systems of meaning, values, and forms of social organization, history, customs and habits." Multicultural often coupled with inter-ethnic relations, is ideally a recognition, respect, and justice against ethnic minorities both concerning the universal rights attached to the rights of individuals and communities that are collective in expressing their culture.

Multicultural education aims to reward cultural differences. Multicultural education recognizes the diversity of ethnic and cultural societies of a nation, as [5] states that:

Religious, linguistic, and national minority, as well as indigenous and tribal people was often subordinated, sometimes forcefully and against their will, to the interest of the state and dominant society. While many people had to discard their own cultures, languages, religions, and traditions and adapt to the alien norms and customs that were consolidated and reproduced through national institutions including the educational and legal system.

Through this multicultural education, all students of different racial and ethnic background, notes, gender, social class, religion, language, and sexual orientation will enjoy the same education. In line with the above opinion, [6] defines "Multicultural education is as an education for people of color." It means multicultural education wants to give an understanding that the difference is a gift of God and characteristic of each individual; they have to accept each other and appreciate each other because the difference is a gift.

The indicators of multicultural education which are in accordance with Clive Black's opinion [7] are as follows:

1. Teaching ethnic student about their own ethnic culture, including perhaps, heritage language instruction;

2. Teaching all students about various traditional cultures, at home and abroad. While such studies can be pursuit in a variety of ways, what is unusually missing is systematic treatment of fundamental issues of culture and ethnicity;

3. Promoting acceptance of ethnic diversity in society;

4. Showing that people of different religions, races, national background and so on are equal worth;

5. Fostering full acceptance and equitable treatment of the ethnic subcultures associated with different religions, race, national background, etc. in one's own country and in other parts of the world;

6. Helping students to work toward more adequate cultural form for them and for society.

Multicultural education should be able to convey to students about their respective cultural identity, cultural diversity, ethnicity, and other races throughout Indonesia as well as abroad, acceptance of cultural diversity within a society, and equality of members of different societies although different religions, races, ethnics, and cultures. If students have already had the knowledge about cultural diversity and how to accept the differences, it is expected that they are able to respect and tolerate the differences in Indonesia.

\section{METHOD}

This research employed a quantitative approach as it is an educational research in which the researcher determines what would be studied, asked specific questions, limited questions, collected measurable data from participants, analyzed the data using statistics, and investigated impartiality, and acted objectively. The research location was at an Indonesian School located in Singapore. The population of this study was all students in the school. While the research subjects in this study were 78 students from all junior high school students and high school students in Singapore School of Singapore.

\section{RESULT}

The Indonesian School in Singapore (SIS) students who are Indonesian citizens come from various parts of Indonesia, and some are foreign descendants and born overseas. This makes SIS's multicultural condition internally. In addition, SIS students are also faced with the state of Singapore's multicultural environment. Singaporeans consist of several ethnics and ethnic groups such as Mandarin, Malay, English, and Tamil. The language of instruction also uses the language of the four largest tribes. Thus, the socio-cultural conditions of SIS are faced with the condition of the citizens of Singapore's diverse schools and neighborhood. In other words, SIS students face the conditions of multiculturalism internally and externally.

To obtain the data range of multicultural education through Civic Education learning obtained from the results of the questionnaire as many as 25 questions distributed to 78 students consisting of each junior high school as many as 42 students and high school level as many as 36 students. Questionnaires that the researchers disseminated are closedquestionnaires, ultimately the respondents did not need to explain further answers of the proposed statement items. The 
scale used in making Likert questionnaire as has been determined that is with the calculation of scores: Strongly Agree (5); Agreed (4); Hesitate (3); Disagree (2), and Strongly Disagree (1).

Multicultural education at the Indonesian School in Singapore is delivered or integrated into all subjects, especially Civic Education subject. Multicultural education to be conveyed to students should include the following indicators: (1) Understanding of each ethnic culture; (2) Understanding of traditional culture at home and abroad; (3) Acceptance of ethnic diversity in the community; (4) The recognition of persons of different religions, races, national backgrounds has the same position; (5) Fair treatment of ethnic subcultures related to different religions, races, national backgrounds in their own country and other parts of the world; and (6) Helping students to have a more socially and culturally appropriate atmosphere.

The results of processing and data analysis of these six aspects are presented using mean data and percentage for each question. The results of the presentation percentage of the application of multicultural education that contains the understanding of ethnic culture are as follows:

TABLE 1. OVERVIEW OF JUNIOR HIGH SCHOOL STUDENTS' PERCEPTIONS OF MULTICULTURAL EDUCATION

\begin{tabular}{|c|c|c|c|c|c|c|}
\hline No. & Indicators & SA & $\mathbf{A}$ & $\mathbf{H}$ & D & SD \\
\hline 1. & Understanding of each ethnic culture & 47,6 & 41,6 & 16,6 & 4,8 & - \\
\hline 2. & Understanding of traditional culture at home and abroad & 40,4 & 41 & 17,2 & 2,4 & - \\
\hline 3. & Acceptance of ethnic diversity in the community & 36,6 & 47,6 & 12,8 & 4,7 & - \\
\hline 4. & $\begin{array}{l}\text { The recognition of persons of different religions, races, national backgrounds has the } \\
\text { same position }\end{array}$ & 42,1 & 30,9 & 19 & 8,3 & 7,1 \\
\hline 5. & $\begin{array}{l}\text { Fair treatment of ethnic subcultures related to different religions, races, national } \\
\text { backgrounds in their own country and other parts of the world }\end{array}$ & 17,6 & 36,2 & 25,7 & 15,2 & 8,7 \\
\hline 6. & Helping students to have a more socially and culturally appropriate atmosphere & 27,9 & 41 & 18,4 & 10,7 & 3,6 \\
\hline \multicolumn{2}{|r|}{$\begin{aligned} \text { Average }\end{aligned}$} & 35,3 & 39,7 & 18,2 & 7,6 & 6,4 \\
\hline
\end{tabular}

Table 1 shows that the results of junior high school respondents' calculations on the understanding of ethnic culture of $47.6 \%$ each answered strongly agree. The average junior high school students agree with the existence of multicultural education that is as much as $39.7 \%$; strongly agree $35.5 \%$; and the rest answered hesitantly; disagree; strongly agree. Understanding of traditional culture at home and abroad as much as $41 \%$ chose to agree. Junior high school students also answered strongly agree to the recognition of different people who have the same position.

\begin{tabular}{|c|c|c|c|c|c|c|}
\hline No. & Indicators & SA & $\mathbf{A}$ & $\mathbf{H}$ & SD & $\mathbf{D}$ \\
\hline 1. & Understanding of each ethnic culture & 20,8 & 59,7 & 16,6 & 11,1 & - \\
\hline 2. & Understanding of traditional culture at home and abroad & 18,7 & 63,2 & 13,2 & 6,4 & - \\
\hline 3. & Acceptance of ethnic diversity in the community & 19,9 & 61,1 & 15,5 & 2,8 & 2,8 \\
\hline 4. & $\begin{array}{l}\text { The recognition of persons of different religions, races, national backgrounds has the } \\
\text { same position }\end{array}$ & 16,6 & 52,8 & 21,3 & 9,2 & - \\
\hline 5. & $\begin{array}{l}\text { Fair treatment of ethnic subcultures related to different religions, races, national } \\
\text { backgrounds in their own country and other parts of the world }\end{array}$ & 14,4 & 68,8 & 13,3 & 5,6 & 5,6 \\
\hline 6. & Helping students to have a more socially and culturally appropriate atmosphere & 24,3 & 72,9 & 5,1 & - & - \\
\hline \multicolumn{2}{|r|}{ Average } & 19,1 & 63 & $\mathbf{1 4 , 1}$ & 7 & 4,2 \\
\hline
\end{tabular}

High school students consider the traditional cultural understanding at home and abroad at a rate of agreeing with the highest average score of $63.2 \%$. From the description of the data above, in general junior and senior high school students in Indonesian School in Singapore showed a good attitude and coexistence in diversity in everyday life. This is indicated by the willingness of students to interact with other groups of different ethnicities, exchange ideas, and be neutral in the face of SARA conflict. The highest average score of junior high school students stated approval of $41 \%$ and high school students $72.9 \%$.

After the percentage of each aspect is known, it is necessary to describe the results of minimum achievement, maximum, average, and standard deviation of all aspects for $\mathrm{X}$ variables related to students' perceptions of multicultural education, which can be described in the table as follows:

TABLE 3. THE DESCRIPTION OF X VARIABLE AT JUNIOR AND SENIOR HIGH SCHOOL LEVELS

\begin{tabular}{|c|c|c|c|c|c|c|}
\hline Variable & Level & N & Min & Max & Mean & Std. Deviation \\
\hline $\begin{array}{c}\text { The students' perception about } \\
\text { multicultural education }\end{array}$ & Junior high school & 42 & 84 & 121 & 99.83 & 8.395 \\
& Senior high school & 36 & 85 & 116 & 99.33 & 7.091 \\
\hline
\end{tabular}

The above table shows that the $\mathrm{X}$ variable related to the students' perceptions of multicultural education has different generated categories between junior and senior high school levels. If described in every level, it is obtained: 1) junior high school with the number of students as many as 42 people has a minimum value of 84 and a maximum value of 121 , an average of 99.83 and the standard deviation of 8.395 ; and 2) senior high school level with 36 students has a minimum score 
of 85 and a maximum score of 116 , an average of 99.33 and a standard deviation of 7.091. Depicted in a graph of the

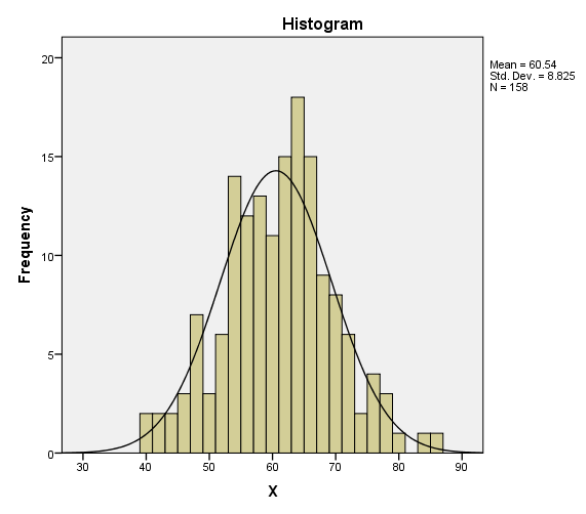

.Junior high school level average score of each level between junior and senior high schools, it can be seen in the following graphs:

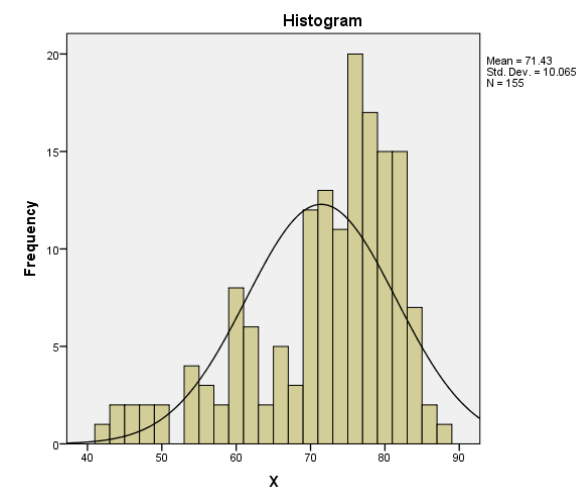

Senior high school level

Fig 1. Average Achievement Levels of Junior and Senior High Schools in Variable X

Junior and Senior High School students of Indonesian School in Singapore have a good perception about multicultural education. This can be analyzed from a questionnaire that has been developed to measure the students' perception of multicultural education. Based on the result of $\mathrm{T}$ test conducted on multicultural education indicator, it can be described that $\mathrm{t}$ count $(-21.8)<\mathrm{t}$ table $(2.00)$; hence, students of Indonesian School in Singapore have positive perception about multicultural education.

\section{DISCUSSION}

Based on specific findings and observations of the school situation, the results of the students' perception of multicultural education can be analyzed from several things: 1) Civic Education learning only has relatively less time so that the teacher only solves the core material; 2) Civic Education learning today, if lack of innovation becomes saturated and boring learning for students; 3) the understanding given to students about multiculturalism is so minimum that students only know the basics; 4) teachers do not relate multiculturalism material with the real world of students (contextual learning); and 5) the teacher is limited in giving examples while the implementation of learning takes less attention.

According to Ricardo L. Garcia [8], three factors in the management of learning namely: (a) the physical environment, (b) the social environment, and (c) the teaching style. In learning, the learners who sit in education require a physical and a social environment that are safe and comfortable. To create a comfortable physical environment, teachers can facilitate learning tools using easy sources and media by utilizing the environment. Therefore, in this learning, teachers are required to have an understanding of the cultural background and characteristics of their students to create conducive physical environment for learning. Meanwhile, a safe and comfortable social environment can be created by teachers through research collaboration, fostering students' interaction with the social environment, presenting interesting facts, and collaborating with other culturally diverse students.

In addition to the physical and social environment, students also need an exhilarating teacher-teaching style. In the learning process, the teacher leadership style is very influential for the presence or absence of students' opportunities to share opinions and make decisions. Teacher leadership styles revolve around authoritarian, democratic, and free. Authoritarian leadership styles do not provide opportunities for students to share their opinions. What teachers teach is determined by the teacher himself/herself. Conversely, the democratic leadership style of teachers provides an opportunity for students to determine the material that students need to learn. Furthermore, teachers who use the free leadership style then the teacher entirely devote to the students to determine the learning materials in the classroom.

\section{CONCLUSION}

Based on the results and discussion of this research, it can be concluded that the students' perception of multicultural education has different generated categories between junior and senior high school levels. Based on the result of $\mathrm{T}$ test conducted on multicultural education indicators, it can be seen that $\mathrm{t}$ count $(-21,8)<\mathrm{t}$ table $(2.00)$; hence, students of Indonesian School in Singapore have positive perception about multicultural education. In general, students of junior and senior high school levels have a good perception about multicultural education. Thus, teachers and students must cooperate consistently and sustainably in implementing multicultural education. Finally, this multicultural education can educate the young generation to maintain harmony relations among community members in diversity. 


\section{REFERENCES}

[1] J. Barndsford, How People Learn: Brain, Main, Experience and School, Washington DC: National Academy Press, 2000

[2] P. Harvey, Hybrids of Modernity: Anthropology, the Nation State and the Universal Exhibition, London: Routledge, 1996

[3] C. Mahfud, Pendidikan Multikultural, Yogyakarta: Pustaka Pelajar Offset, 2011

[4] B. Parekh, Rethinking Multiculturalism: Cultural Diversity and Political Theory, London: MacMillan Press, 2000

[5] R. Stavenhagen, Education for a Multicultural World, Learning the Treasure Within, Paris: UNESCO, 1996
[6] J. A. Banks, Teaching Strategies for Ethnic Studies, Newton: Allyn and Bacon, 1984

[7] N. Naim \& A. Sauqi, Pendidikan Multikultural Konsep dan Aplikasi, Yogjakarta: Ar-Ruzz Medi Group, 2010

[8] A. Aly, Pendidikan Multikultural dalam Tinjauan Pedagogik, Representated at Seminar Pendidikan Multikultural sebagai Seni Mengelola Keragaman, in Culture Study Centre and Social Changing (PSB-PS) Universitas Muhammadiyah Surakarta, Saturday 8 January 2005. 